\title{
Responsible Corporate Governance in Europe
}

In Aluchna, M. \& Idowu, S.O., Responsible Corporate Governance. Springer, Heidelberg, Switzerland.

\author{
Mark Anthony Camilleri* \\ Department of Corporate Communication, University of Malta
}

\begin{abstract}
The latest European Union's (EU) guiding policies are encouraging big businesses and stateowned organisations to provide a fair and truthful view of their respective entities' environmental, social and governance (ESG) performance. At present, European member states are transposing directive 2014/95/EU on non-financial reporting. The EU's "comply or explain" approach has presented a significant step forward toward the corporations' active engagement on corporate governance disclosure and transparency. Hence, this chapter makes specific reference to some of the corporations' best practices as it identifies areas for improvement in corporate governance issues. It explains how three major European banks have reviewed the roles and responsibilities of corporate boards and management. In many cases, they have anticipated any regulatory, legal, contractual, social and market-driven obligations as they helped stakeholders to exercise their rights. This contribution contends that there are significant implications for financial services corporations who intend following the right path toward responsible corporate governance and ethical behaviours.
\end{abstract}

*Resident Academic Lecturer, Department of Corporate Communication, University of Malta, MALTA Email: mark.a.camilleri@um.edu.mt Tel.+3562340 3742 


\section{Introduction}

The corporate social responsibility (CSR) practices of huge multinationals affect millions, perhaps billions of people across the world, whether through the products they supply, the people they employ, the communities they locate in or the natural environments they affect. Over the last few decades, the resurgence of corporate governance could have been triggered by corporate irresponsibility and scandals. Debatably, corporations are not only strategicallyrational; they are also morally-obliged to uphold their stakeholders' interests, at all times. While corporate scandals have given considerable mileage to business ethics and CSR issues; businesses ought to focus their energies on their core economic functions of producing goods and services, whilst maximising returns for their primary legitimate interest groups, namely shareholders (Harford, Mansi \& Maxwell, 2012; Shleifer \& Vishny, 1997; Donaldson \& Preston, 1995; Friedman, 1970). In this light, responsible corporate governance determines the systems, principles, and processes by which large firms or state-owned entities are governed.

The corporate governance principles and codes have been developed to guide large organisations (with more than 500 employees) to balance the distribution of rights and responsibilities of all stakeholders. During these last decades the big entities were constantly reminded that they had obligations towards; shareholders, employees, investors, creditors, suppliers, local communities, customers, and policy makers. Moreover, organisational leaders were instructed on their duties and responsibilities pertaining to the composition of the board of directors as they had to respect their shareholders' rights. Notwithstanding, sound corporate governance demanded corporate officers and board members to give life to an organisation's guiding values, to create an environment that supports ethically sound behaviours, and to instil a sense of shared accountability among employees (Paine, 1994). Therefore, the driving force of corporate governance ought to be characterised by integrity, honesty and organisational ethics. Ethical values shape the search for opportunities, the design of organisational systems, and the decision-making process. These responsible principles help to define what a company is and what it stands for. They provide a common frame of reference and serve as a unifying force across different functions, lines of business, and employee groups (Paine, 1994). Stakeholders expect accountability and transparency from large organisations. Hence, organisations are expected to clarify and make publicly known the roles and responsibilities of the board and management. Corporate entities are 
encouraged to implement procedures to independently verify and safeguard the integrity of the company's financial reporting. Such disclosures of material matters concerning the organisation should be timely and balanced in order to ensure that all investors have access to clear and factual information.

This contribution explains how corporate governance is not an end in itself. It is a means to create market confidence and business integrity. Responsible corporate governance is essential for companies that need access to equity capital for long term investment. Access to equity capital is particularly important for future oriented growth companies, particularly in the financial services industry. This chapter presents a review of some of the international corporate governance principles as it reports about the voluntary guidelines on non-financial reporting in the EU. This is followed by a content analysis of the corporate governance practices of three major European banks hailing from different contexts. More specifically, this research evaluates formal and informal structures, as well as the processes and disclosures procedures that exist in oversight roles and responsibilities within the financial services sector. The underlying objective of this analysis is to scrutinise the banks' corporate governance micro/macro dimensions as they need to respond to regulatory pressures and stakeholder demands. The discussion of the three banks provides a useful illustration of how corporate governance practices can be implemented, and it does provide an indication of how some practices may differ from institution to institution (and by country). Yet, there are also certain practices that remain similar across the EU countries. Therefore, this chapter sheds light on principles and good practices of corporate governance in three major European banks, namely; ING Bank, Deutsche Bank and UniCredit. It addresses the rights of directors, managers, shareholders and employees among other interested parties. This research critically evaluates how these stakeholders are engaging in corporate decision making, in the light of the latest developments in corporate governance policy.

\section{Corporate Governance Regulatory Principles and Codes}

The corporate governance principles have initially been articulated in the "Cadbury Report" (Jones \& Pollitt, 2004) and have also been formalised in the "Principles of Corporate Governance" by the Organisation for Economic Cooperation and Development (Camilleri, 2015a; Lazonick \& O'Sullivan, 2000). Both reports have presented general principles that help large organisations in corporate governance decisions. Subsequently, the federal 
government in the United States enacted most of these principles that were reported in the Sarbanes-Oxley Act in 2002 (Abbott, Parker, Peters \& Rama, 2007). Different governments and jurisdictions have put forward their very own governance recommendations to stock exchanges, corporations, institutional investors, or associations (institutes) of directors and managers, sometimes with the support of intergovernmental organisations. With regards to social and employee related matters, large organisations could implement the International Labour Organisation (ILO) conventions that promote fair working conditions for employees (Fuentes-García, Núñez-Tabales \& Veroz-Herradón, 2008). The corporate disclosure of nonfinancial information includes topics such as; social dialogue with stakeholders, information and consultation rights, trade union rights, health and safety and gender equality among other issues (EU, 2014). The compliance with such governance recommendations is usually not mandated by law. Table 1 presents a selection of corporate governance principles:

\section{Table 1: A Non-Exhaustive List of Corporate Governance Principles}

The Cadbury Report (1992)

International Corporate Governance network (1995)

OECD's Principles of Corporate Governance 1999 (revised in 2004)

Sarbanes-Oxley Act (2002)

World Business Council for Sustainable Development (2004)

The International Finance Corporation and the UN Global Compact (2009)

Equator principles (2010)

EU's Directive on Disclosure of Transparency 2013/50/EU (2013)

EU's Directive on Non-Financial Disclosures 2014/95/EU (2014)

(Compiled by the author)

Most of these principles have provided reasonable recommendations on sound governance structures and processes. In the main, these guidelines outlined the duties, responsibilities and rights of different stakeholders. In the pre-globalisation era, non-shareholding stakeholders of business firms were in many cases sufficiently protected by law and regulation (Schneider \& Scherer, 2015). In the past, the corporate decisions were normally taken in the highest echelons of the organisation. The board of directors had the authority and power to influence shareholders, employees and customers, among others. This board consists of executive and 
non-executive directors. The organisations' ownership structure, and the composition of the top management team could influence corporate social performance (Lau, Liu \& Liang, 2014). Notwithstanding, the non-executive directors could also have a positive impact on CSR reporting (Sharif \& Rashid, 2014). However, these assumptions have become partly untenable with the diminution of public steering power and the widening of regulation gaps (Lau et al., 2014). In many cases, stakeholders of business firms lack protection by nation state legislation. Notwithstanding, with the inclusion of stakeholders, corporate governance may compensate for lacking governmental and regulatory protection and could contribute to the legitimacy of business firms (Miller \& del Carmen Triana, 2009). Schneider and Scherer (2015) argued that the inclusion of stakeholders in organisational decision processes on a regular basis can be regarded as the attempt of business firms to address the shortcomings of a shareholder-centred approach to corporate governance. This casual consultation with stakeholders could often be characterised by unequal power relations (Banerjee, 2008).

Previous research may have often treated the board as a homogeneous unit. However, at times there could be power differentials within boards (Hambrick, Werder \& Zajac, 2008). Boards are often compared to other social entities, in that they possess status and power gradations. Obviously, the chief executive will have a great deal of power within any organisation. In addition, the directors may include current executives of other firms, retired executives, representatives of major shareholders, representatives of employees and academics. Who has the most say? Is it the directors who hold (or represent) the most shares or does it reflect the directors' tenures? It could be those who hold the most prestigious jobs elsewhere, or the ones who have the closest social ties with the chairman or chief executive. These power differentials within the echelons of top management teams could help to explain the firms' outcomes. Ultimately, the board of directors will affect processes and outcomes.

A more macro perspective on informal structures opens up new questions regarding the roles of key institutional actors in influencing the public corporation (Hambrick, Werder \& Zajac, 2008). Although researchers have long been aware of different shareholder types, there has been little consideration of the implications of shareholder heterogeneity for the design and implementation of governance practices. Managers and shareholders, as well as other stakeholders, have wide variations of preferences within their presumed categories. For instance, there are long-term and short-term-oriented shareholders, majority and minority shareholders, and active and passive shareholders (Hambrick et al., 2008). In addition, the 
rise of private equity funds may have created a whole new shareholder category. This group is becoming more and more influential. The idea of heterogeneity within stakeholder categories, including diversity among equity shareholders, will become a popular topic in future governance research (Miller \& del Carmen Triana, 2009). Growing shareholder activism raises questions that could have been overlooked in the past. Who runs, and who should run the company? Corporate governance does not begin and end with principals, agents, and contracts. Beyond the obvious roles of regulatory authorities and stock exchanges, we are witnessing an increasing influence from the media, regulatory authorities, creditors and institutional investors, among others. These various entities may have a substantial effect on the behaviours of executives and boards of public companies. Arora and Dharwadkar (2011) had suggested that effective corporate governance could discourage violation of regulations and standards. Jizi, Salama, Dixon and Stratling (2014) examined the impact of corporate governance, with particular reference to the role of board of directors, on the quality of CSR disclosure in US listed banks' annual reports after the US sub-prime mortgage crisis. Jizi et al. (2014) implied that the larger boards of directors and the more independent ones are in a position to help to promote both shareholders' and other stakeholders' interests. They found that powerful CEOs may promote transparency about banks' CSR activities for reputational concerns. Alternatively, the authors also pointed out that this could be a sign of managerial risk aversion. Recently, many businesses have linked executive pay to non-financial performance. They tied executive compensation to sustainability metrics such as greenhouse gas (GHG) reduction targets, energy efficiency goals and water stewardship; in order to improve their financial and non-financial performance (CERES, 2012). In a similar vein, Jo and Harjoto (2011) have found that CSR is correlated with governance characteristics, including board independence and institutional ownership. They posited that this finding supports the conflict-resolution hypothesis as opposed to the over-investment and strategic-choice arguments as CSR engagement positively influences operating performance and firm value. Jizi et al. (2014) also indicated that the two board characteristics usually associated with the protection of shareholder interests (board independence and board size) are positively related to CSR disclosure. Manasakis, Mitrokostas and Petrakis (2013) suggested that businesses should recruit sociallyresponsible CEOs and delegate them to instil their CSR ethos on the organisations' stakeholders. They contended that these individuals could act as a commitment device for the firms' owners and toward consumers. 
Moreover, Lau et al. (2014) have examined the effects of corporate governance mechanisms on CSR performance to gain legitimacy in a changing institutional context. They maintained that Chinese firms had to adopt global CSR practices in order to remain competitive. Adaptive governance ought to incorporate strategic and monitoring activities that determine the way companies enact their responsibilities toward shareholders and other stakeholders (Young \& Thyil, 2014). Relevant contextual factors including; the economic environment, national governance system, regulation and soft law, shareholders, national culture, behavioural norms and industry impacts could affect corporate governance. In their philosophical stance, Lau and Young (2013) held that there are different realities that affect corporate governance. They went on to suggest that it is important to explore hybrid solutions into an integrated framework to lessen the possibility of bottlenecks and any emerging incongruities. Rahim and Alam (2013) also argued that corporate self-regulation in less vigilant environments could be incentivised by regulators and other stakeholders. Notwithstanding, the firms who voluntarily disclose more CSR information had better corporate governance ratings (Chan, Watson \& Woodliff, 2014). Such businesses are usually larger; belong to higher profile industries; and are highly leveraged. Mason and Simmons (2014) suggested a holistic approach to corporate governance and social responsibility that integrate companies, shareholders and wider stakeholder concerns. They argued that this is attainable if companies delineate key stages of the governance process and align their profitcentres and social responsibility concerns to produce a business-based rationale for minimising risk and mainstreaming CSR.

Interestingly, the latest European Union (EU) Directive 2014/95/EU on non-financial disclosures has encouraged large undertakings to use relevant non-financial key performance indicators on environmental, social and governance matters (Camilleri, 2015b).

\section{European Corporate Governance Guidelines}

On the 29th September 2014, the European Council has introduced amendments to its previous Accounting Directive (2013/34/EU). The EU Commission has been mandated by the European Parliament to develop non-binding guidelines on the details of what nonfinancial information ought to be disclosed by large "public interest entities" operating within EU countries. It is hoped that non-financial reporting will cover social and environmental issues, including; human rights, anti-corruption and bribery matters as expressed in the UN Guiding Principles on Business and Human Rights (the "Ruggie Principles") and OECD's 
Guidelines for Multinational Enterprises (ECCJ, 2014). This recent, directive has marked a step forward towards the hardening of human rights obligations for large organisations with a staff count of more than 500 employees. At the moment there are approximately 6,000 large undertakings and groups across the EU. Public interest entities include all the undertakings that are listed on an EU stock exchange, as well as some credit institutions, insurance undertakings and other businesses so designated by the EU's member states. Their disclosures are expected to feature a brief description of the entities' business models, including their due diligence processes resulting from their impact of their operations. Corporations (or state owned organisations) should also explain how they are preventing human rights abuses and/or fighting corruption and bribery. This EU directive has emphasised materiality and transparency in non-financial reporting. It also brought up the subject of diversity at the corporate board levels. It has outlined specific reference criteria that may foster wider diversity in the composition of boards (e.g. age, gender, educational and professional background). The EU Commission has even suggested that this transparency requirement complements the draft directive about women on boards. Of course, this new directive will still allow a certain degree of flexibility in the disclosures' requirements. As a matter of fact, at the moment it does not require undertakings to have policies covering all CSR matters. Yet, businesses need to provide a clear and reasoned explanation for not complying with the EU's directive. Therefore, non-financial disclosures do not necessarily require comprehensive reporting on CSR matters, but it encourages the disclosure of information on policies, outcomes and risks (ECCJ, 2014). Moreover, this directive gives undertakings the option to rely on international, European or national frameworks (eg. the UN Global Compact, ISO 26000) in the light of the undertaking's characteristics and business environment. It is envisaged that these revised non-financial reporting requirements will be published as from financial year 2017. However, many European corporations, including multi-national banks are already following these voluntary corporate governance principles.

\section{Methodology}

This empirical investigation presents case studies of large multinational firms within the financial services industry. It represented a "strategy of research that is concentrated on the comprehension of the dynamics that characterise specific contexts (Eisenhardt, 1989, p. 532) 
of corporate governance reporting in Europe. It involved an inquiry of data that is contextdependent (Yin, 2009). Therefore, the research design considered the observational conditions before setting a framework for analysis. The first phase of this research defined the identifying units of analysis in the volume of available data. The researcher drew a representative purposive sample of the largest European financial services organisations in different EU contexts. In fact, this study described, explained and shed light on the dynamics of corporate governance reporting of three major banks, namely; ING Bank (2014), Deutsche Bank (2015) and UniCredit's (2015). Together these banks's total assets amounted to more than USD3800bn (Relbanks, 2015).

The researcher conducted an open analysis of these banks' hypertexts as he identified the dominant messages and subject matters within their disclosures. A dictionary-based approach set up a list of categories that were derived from a frequency list of words. The researcher controlled the distribution of words and their respective categories (of their chosen analytical constructs) over the texts. The coding process often involved the interpretation of semantic text, including technical terms and industry jargon. Such a fieldwork approach involved the analysis of organisational processes and practices of social accounting (Del Baldo, 2012; Adams, 2002).

This inferential step uncovered the coded data as it extracted relevant and material information on the European banks' internal factors (organisational structures, internal microprocesses, their corporate characteristics and the general contextual factors. It explained how European corporations in the financial services industry were disclosing their governance procedures and processes following the EU directive 2014/95/EU on non-financial disclosures. In general terms, the analysis of the European banks' governance disclosures involved a meaningful, comprehensive view of the position and performance on issues relating to the diversity in boards, the shareholders' rights, as reported on the duties and responsibilities of internal and external auditors. Specifically, the three case studies scrutinised the organisations' management and supervisory structures in corporate boardrooms; in order to analyse the firms' accountability and transparency toward their stakeholders.

The content analysis methodological stance describes what is being disclosed by the respective entity; but may not necessarily reveal the underlying motives for the observed pattern (i.e. 'what' is reported, but not 'why'). This qualitative approach possesses its inherent 
limitations. For this reason, the researcher has taken preventative steps to ensure the reliability and validity of his findings. The researcher annotated the "underlying themes" and interpreted them through a standardised content analysis grid that has facilitated the coding process. This grid was consistently used across all cases during the data gathering process. This stratagem has helped the researcher to identify the general themes of the corporate governance reports of the three bank and to make comparisons and generalisations of their disclosures.

\section{Analysis of the Non-Financial Disclosures of Corporations in Financial Services}

\section{(i) ING Bank}

ING Groep N.V. (that is being referred to as ING) is a global financial institution with its base in Amsterdam, Netherlands. At the time of this study, the company had more than 52,000 employees in over 40 countries. Every year, ING reports about its corporate governance policies and practices to the Monitoring Committee (also known as the 'Frijns Committee'). For the record, the Monitoring Committee's "Dutch Corporate Governance Code" became effective as of the 1st January 2004. This "Code" consists of the principles and related best-practice provisions that are intended for all companies whose registered offices are in the Netherlands and whose shares or depositary receipts for shares have been admitted to a listing on a stock exchange, or more specifically to trading on a regulated market or a comparable system. This Code is intended for all large undertakings (with a balance sheet value $>€ 500$ million) and whose shares or depositary receipts for shares have been admitted to trading on a multilateral trading facility or a comparable system (DCGC, 2016).

The Code contains principles and best practice provisions that regulate relations between the management board, the supervisory board and the shareholders (i.e. the general meeting of shareholders). Compliance with the Code's principles is in accordance with the 'apply or explain' principle. In other words, the principles and best practice provisions of the Code must be applied unconditionally or an explanation ought to be given for any departure from them. The Code is divided into five chapters: compliance with and enforcement of the Code; the management board; the supervisory board; the shareholders and the general meeting of shareholders; the audit of the financial reporting and the position of the internal audit function and the external auditor. 
ING Group complies with these provisions on an annual basis. In its General Meeting, ING expressly indicates to what extent it has applied the best-practices in this code. If it did not do so, the company is bound to explain why and to what extent it has not applied these provisions. ING has a two-tier board structure consisting of the Executive Board and the Supervisory Board. ING's Executive Board (Management Board) is responsible for day-today management of the business as well as its long-term strategy. ING's management board is accountable to the supervisory board and to the general meeting, whilst taking into consideration the interests of the company's stakeholders (ING, 2014). It is responsible for managing the risks associated with the company activities, for financing the company, and to control systems (for monitoring and reporting) in liaison with the supervisory board and the audit committee.

The Supervisory Board is responsible for controlling management performance and advising the Executive Board. It comprises outside directors who are involved in five permanent committees: the Audit Committee, the Risk Committee, the Remuneration Committee, the Nomination Committee and the Corporate Governance Committee. All committees are totally independent of ING as each committee has its own charter which describes the powers and duties that have to comply with applicable regulation, such as the US Sarbanes-Oxley Act. For example, one of the remits of the supervisory board is to determine the level and structure of the remuneration of the members in the management board. This board also takes into account; the results, the share price performance and non-financial indicators that are relevant to the long-term objectives of the company, with due regard to relevant risks.

The shareholders are not only interested in getting their return on investment, but they also have a say in the decision-making of ING bank. In fact, they are entitled to voting rights. Each share in the capital of ING Groep N.V. gives entitlement to cast one vote. Shareholders and depositary-receipt holders may exercise their voting rights even if they do not attend a shareholders' meeting. They can enable a proxy to a third party to do so on their behalf. The shareholders have the right to appoint and dismiss members in the executive and supervisory boards during ING's general meeting. According to the Dutch Financial Supervision Act, the shareholders and holders of depositary receipts of ING Groep N.V. are required to provide updated information on their holdings once they cross threshold levels of 3\%, 5\%, 10\%, 15\%, $20 \%, 25 \%, 30 \%, 40 \%, 50 \%, 60 \%, 75 \%$ and $95 \%$. The shares granted to the members in the management board members shall be retained for a period of at least five years or until at 
least the end of their employment (if this period is shorter). The number of shares to be granted is dependent on the achievement of their previously set targets.

The corporate audit services (CAS) is ING's internal audit group that services ING Bank and the ING Group. It reports to the Executive Board and the Audit Committee and is present at the meetings of the Audit Committee. CAS's mission, its scope of work, its authority and responsibilities are laid down in the Internal Audit Charter that is endorsed by the CEO or Executive Board. Finally, it is also approved by the Audit Committee. CAS's mission is to provide an independent assessment of the design and effectiveness of internal controls over the risks to ING's business performance. In carrying out this work CAS provides specific recommendations toward improving the governance, risk management, internal control systems and regulatory compliance processes. The budget for CAS operations is approved by the Audit Committee on an annual basis. CAS's annual risk-based audit plans for ING Bank and ING Group are reviewed by the Executive (Management) Board and approved by the Audit Committee. CAS also initiates a periodic exchange of its risk analysis and audit planning results with the external auditor. It submits periodic reports, with key performance indicators (including audit plan realisation and implementation of recommendations) to the Audit Committee and Executive (Management) Board. This includes an annual report on the adequacy and effectiveness of ING's systems of control, which comprise a summary of internal audit activity results and key issues. CAS is subject to an independent quality review at least every five years.

The Dutch law requires that the company's external auditors should be appointed at the general meeting and not by the audit committee. The external auditor performs the audit on the consolidated financial statements of ING Groep N.V., ING Bank N.V. and the statutory financial statements of their subsidiaries. In this role, the external auditor attends meetings of the Audit Committee and is present during the annual General Meeting of Shareholders (AGM). As part of the audit engagement, the external auditor issues a management letter to the Executive (Management) Board and the Audit Committee, which identifies (potential) issues pertaining to the adequacy and effectiveness of the governance, risk and control framework. ING's Supervisory Board will make recommendations to the AGM once every four years for the appointment of a prospective external auditor. ING's policy requires the auditor to provide the Audit Committee with a full overview of all services provided to ING 
Group, including related fees that should be supported by detailed information. This overview is evaluated on a quarterly basis by the Audit Committee.

In contrast to the Sarbanes-Oxley Act of 2002, the Dutch Corporate Governance Code contains a 'comply-or-explain' principle. This is consistent with the latest EU (2014) directive. Therefore, any deviations to the code are permissible as long as they are reasonably explained. When these deviations are approved by the general meeting, the company is deemed to be in full compliance with the Code.

\section{(ii) Deutsche Bank}

Deutsche Bank AG is a global financial services corporation that has its headquarters in Frankfurt, Germany. It is a listed company and has more than 100,000 employees in over 70 countries. Therefore, Deutsche Bank is subject to the essential statutory regulations of the German Corporate Governance Code. This Code describes the legal regulations for management and the supervision of German listed companies, as per Aktiengesetz (German Stock Corporation Act). Other elements of the Code are derived from international and national-acknowledged standards for good and responsible corporate governance. These are presented as principles in the form of recommendations and suggestions that are not mandatory. For instance, the Deutsche Corporate Governance Kodex recommends that the amount of compensation for the Management Board members is to be capped, both overall and with regard to variable compensation components. In 2014, Deutsche Bank AG did not set a cap (limit) for the pay-out amount of the deferred equity-based compensation, so it has not complied with the Code's recommendation in No. 4.2 .3 (2) sentence 6. Any deviations from the recommendations ought to be explained and disclosed with the annual declaration of conformity (as per the EU's Comply or Explain principle). Besides giving reasonable recommendations and suggestions that reflect the best practice of corporate governance, the Code aims at enhancing the German corporate governance system's transparency and comprehensibility, in order to strengthen the confidence of international and national investors, clients, employees and the general public in the management and supervision of German listed companies (DCGK, 2016). 
Deutsche Bank complies with the German Corporate Governance Code as per section 161 of the German Stock Corporation Act. The Code clarifies the obligation of the Management Board and the Supervisory Board to ensure the continued existence of the enterprise and its sustainable creation of value in conformity with the principles of the social market economy (interest of the enterprise). The Supervisory Board appoints, supervises and advises the members of the Management Board and is directly involved in decisions of fundamental importance to the enterprise. The members of the Supervisory Board are elected by the shareholders at the General Meeting. The Supervisory Board of Deutsche Bank must be composed in such a way that its members as a group possess the knowledge, ability and expert experience to properly complete its tasks. In particular, the Supervisory Board members should have sufficient time to perform their mandates. The composition of the Supervisory Board shall have an adequate number of independent members and shall not have more than two former members of the Management Board of Deutsche Bank AG. The Supervisory Board has established the following seven standing committees, including; a Chairman's Committee; a Nomination Committee: an Audit Committee; a Risk Committee, an Integrity Committee; a Compensation Control Committee and a Mediation Committee (Deutsche Bank, 2015).

The Management Board submits to the General Meeting the Annual Financial Statements, the Management Report, the Consolidated Financial Statements and the Group Management Report. The General Meeting resolves on the appropriation of net income and the discharge of the acts of the Management Board and of the Supervisory Board and, as a rule, elects the shareholders' representatives to the Supervisory Board and the auditors. Furthermore, the General Meeting resolves on the content of the Articles of Association, including: the purpose of the company; inter-company agreements and transformations; the issuance of new shares, convertible bonds and bonds with warrants; as well as the authorisation to purchase own shares. It also authorises the remuneration system for the members of the Management Board.

The shareholders exercise their rights before or during the General Meeting. In principle, each share carries one vote. There are no shares with multiple voting rights, preferential voting rights (golden shares) or maximum voting rights (Deutsche Bank, 2015). When new shares are issued, shareholders, in principle, have pre-emptive rights corresponding to their share of the equity capital. Each shareholder is entitled to participate in the General Meeting 
to take the floor on matters on the agenda and to submit materially relevant questions and proposals. At least once a year the General Meeting is to be convened by the Management Board giving details of the agenda. The convening of the meeting, as well as the reports and documents, including the Annual Report, required by law for the General Meeting are to be made easily accessible to the shareholders on the company's internet site together with the agenda. If a postal vote is offered, the same applies to the necessary forms. Deutsch Bank facilitates the personal exercising of shareholders' voting rights and the use of proxies. The Management Board could arrange for the appointment of a representative to exercise the shareholders' voting rights in accordance with relevant instructions. This representative should also be reachable during the General Meeting. The company also makes it possible for shareholders to follow the General Meeting using modern communication media (e.g. through the Internet). Beyond Deutsche Bank's statutory obligations to report and disclose dealings in shares of the company without delay, the ownership of shares in the company or related financial instruments by the Management Board and Supervisory Board members shall be reported if they exceed $1 \%$ of the shares issued by the company. If the entire holdings of all members of the Management Board and Supervisory Board exceed $1 \%$ of the shares issued by the company, these shall be reported separately to the Management Board and Supervisory Board in the Corporate Governance Report.

Prior to submitting a proposal for election, the Supervisory Board or, respectively, the Audit Committee shall obtain a statement from the proposed auditor stating whether, and where applicable; which business, financial, personal and other relationships exist between the auditor and its executive bodies and head auditors on the one hand, and the enterprise and the members of its executive bodies on the other hand, that could call its independence into question. This statement shall include the extent to which other services were performed for the enterprise in the past year, especially in the field of consultancy, or which are contracted for the following year. The Supervisory Board shall agree with the auditor that the Chairman of the Supervisory Board or, respectively, the Audit Committee will be informed immediately of any grounds for disqualification or partiality occurring during the audit, unless such grounds are eliminated immediately. The Supervisory Board commissions the auditor to carry out the audit and concludes an agreement on the latter's fee. The Supervisory Board shall arrange for the auditor to report without delay on all facts and events of importance for the tasks of the Supervisory Board; which arise during the performance of the audit. Deutsche Bank's Supervisory Board shall arrange for the auditor to inform it if during the performance 
of the audit, the auditor comes across facts which show a misstatement by the Management Board and Supervisory Board on the Code. The auditor takes part in the Supervisory Board's deliberations on the Annual Financial Statements and Consolidated Financial Statements and reports on the essential results of its audit (Deutsche Bank, 2015).

\section{(iii) UniCredit}

UniCredit S.p.A is an Italian commercial bank operating in 17 countries with over 144,000 employees, in an international network that spans 50 markets. Its joint stock company adopts the so-called traditional management and control system. This system is based on the existence of two corporate bodies; the Board of Directors and the Board of Statutory Auditors. The Board of Directors supervise and manage the company, whereas the Board of Statutory Auditors oversees the management. Moreover, the accounting supervision is entrusted to an external auditing firm. UniCredit's overall corporate governance framework has been defined in its current provisions that reflect the recommendations of the Corporate Governance Code for listed companies (Borsa Italiana, 2015). Each Italian company with listed shares (the "issuer") follows this "Code". They are expected to disclose their corporate governance report and proprietary shareholdings with accurate, concise, exhaustive and easily understandable information. This is synonymous with the EU's (2014) comply or explain directive as each single recommendation contained within the principles and criteria ought to be implemented during the period covered by the report. The corporate governance disclosures should; (a) explain in what manner the company has departed from the recommendation; (b) describe the reasons for the departure, whilst avoiding vague and formalistic expressions; (c) describe how the decision to depart from the recommendation was taken within the company; (d) where the departure is limited in time, explain when the company envisages complying with a particular recommendation; (e) if it is the case, describe the measure taken as an alternative to the relevant non-complied recommendations and explain how such alternative measure achieves the underlying objective of the recommendation or clarify how it contributes to their good corporate governance (Unicredit, 2015).

The main principles of the Italian code specify the rights, duties and responsibilities of various stakeholders, including; the directors, statutory auditors and shareholders among others. All the members of the Board of Directors and the Board of Statutory Auditors are 
appointed by the Shareholders' Meetings on the basis of a proportional representation mechanism (voto di lista). This voting system features lists of candidates competing against one another in order to ensure the election of minority shareholders representatives. UniCredit's boards have to comply with specific rules concerning the appointment of their members in accordance with the gender composition criteria provided for by law (see Clauses 20 and 30 of the Articles of Association). They also cover professional experience, integrity and independence requirements. As regards the appointment and the requirements of the Board of Statutory Auditors members, it must be pointed out, inter alia, that: UniCredit's Articles of Association stipulate that two permanent auditors as well as two stand-in ones are reserved to the minorities and that the Chairman is appointed by the Shareholders' Meeting among the auditors elected by the minorities. In addition, at least two permanent auditors and one stand-in auditor must be listed in the national Rolls of Auditors; which must have carried out the legal auditing of accounts for a period of no less than three years (Unicredit, 2015).

The Directors' term of office spans three operating years, except where a shorter term is established at the time they are appointed, and ends on the date of the Shareholders' Meeting that is convened for the approval of the accounts (relating to the last operating year in which they were in office). The Executive Management Committee has been set up to ensure the effective steering, coordination and control of the group's undertakings. The Ordinary Shareholders' Meeting appoints 5 permanent Statutory Auditors, from whom it also elects the Chairman and four substitute Auditors. The permanent and substitute Auditors may be reelected. The Chairman of the Board of Statutory Auditors is appointed by the Shareholders' Meeting from among the permanent Auditors that are elected by the minority shareholders. The Supervisory Body pursuant to Legislative Decree 231/2001 prescribes the establishment of an internal Supervisory Body. Its duty is to supervise the organisation's compliance with responsible corporate governance. The Supervisory Body of UniCredit consists of 5 members, including two external members and three executives in "apical" positions with guidance, support and control functions.

The Internal Control System (ICS) involves a set of rules, procedures and organisational structures. ICS aims to ensure that corporate strategy is implemented through effective corporate processes. It strives to ensure the reliability and integrity of accounting and management data. UniCredit's Group Risk Management (GRM) function ensures that there is regulatory compliance as it manages risk, including; credit risk, market risk, liquidity risk and 
operational and reputational risk. UniCredit's Internal Audit Department verifies the conformity of the group companies' conduct with the Parent Company's guidelines as it monitors the effectiveness of internal control systems.

The shareholders' meetings are called on to pass resolutions pursuant to the terms and conditions that are laid down in the bank's Articles of Association. In Ordinary Sessions, the shareholders' meetings are convened at least once per year, within 180 days of the end of the financial year, to pass resolutions on topics over which they have jurisdiction. Specifically, in an ordinary session, the shareholders' meetings are called upon to approve the balance sheet and to resolve on the allocation of the profit, appoint directors and statutory auditors, and appoint external auditors for statutory certification of the accounts. Additionally, the shareholders' meetings are called upon to pass resolutions on any early termination of the directors or auditors, or on the termination of the appointment of external auditors for the statutory certification of the accounts. Moreover, ordinary session shareholders' meetings also approve: (i) the remuneration policies for supervisory, management and control bodies as well as for employees; (ii) equity-based compensation schemes. Shareholders' meetings are convened in extraordinary sessions as and when required to pass resolutions on any of the issues over which they are empowered (pursuant to applicable law). Specifically, in extraordinary sessions, the shareholders' meetings pass resolutions on amendments to the Articles of Association and on transactions of an extraordinary nature such as capital increases, mergers and demergers.

Both ordinary and extraordinary shareholders' meetings are convened, according to law, via a notice published on the company's website and through the other methods envisaged by both legal and regulatory provisions. The Board of Directors shall publish a report at the Company's registered office, on its website, and through the other channels on each item on the agenda and make the said report publicly available. The Chairman of the Shareholders' Meeting is fully empowered to moderate the meeting proceedings in compliance with the principles, terms and conditions established by the provisions in force, as per the General Meeting Regulations. All those who hold voting rights are eligible to attend the shareholders' meetings. Any person that is entitled to vote may choose to be represented in a shareholders' meeting by proxy. These shareholders have to indicate the name of one or more possible representative's substitutes. 
Shareholders who, even jointly, represent at least $0.50 \%$ of the UniCredit share capital, may ask for the shareholders' meeting agenda to be integrated and / or to submit resolution proposals on items already on the agenda (according to the cases, methods, terms and conditions outlined in Section 126-bis of the Legislative Decree no. 58/98 and in the Articles of Association). The requests, together with the documentation certifying the ownership of the shareholding, must be submitted in writing. Shareholders requesting additions to the agenda must prepare a report stating the reasons for their resolution proposals on the new matters they propose for discussion; such report shall be forwarded to the Board of Directors by the final deadline for the submission of the request for addition. Questions received by the Company prior to the Meeting shall be answered - subject to the right thereto being ascertained - during the Meeting itself at the latest. The Company is entitled to provide a single answer to questions on the same subject matter (Unicredit, 2015).

\section{Discussion}

This contribution has reported that the European banks are following specific national provisions that have introduced industry codes of conduct. Notwithstanding, these financial institutions are also complying with the EU's directive 2014/95/EU. The comply or explain directives can be seen as providing market-based solutions that may suit both the company and its shareholders without the need for regulatory intervention. This voluntary instrument is based on shared beliefs and institutional arrangements with stakeholders. The corporations that do not comply with the codes are expected to explain how their actual practices are consistent with responsible corporate governance and the achievement of their business objectives.

In a similar vein, institutional arrangements need to ensure that explanations are credible to the regulatory authorities. These arrangements may relate to different corporate governance matters, including; ownership issues, the role of intermediaries, shareholder rights and engagement, stock markets and the incentives that all these arrangements create. Institutional arrangements will determine whether shareholders will play the stewardship role expected of them in a comply-or-explain scenario. They are expected to challenge companies' explanations and engage with boards if they are unconvincing to them. For example, there are 
provisions (pertaining to the comply-or-explain methodology) which suggest that the roles of the chairman and chief executive should not be exercised by the same individual; the board should appoint a senior independent director; at least half the board, excluding the chairman should comprise independent non-executive directors; there should be nomination, audit and remuneration committees and separate sections of the annual report to describe the work of the nomination and audit committees; and the directors should have access to independent professional advice and the services of the company secretary, among other issues.

Therefore, the comply or explain is an approach that positively recognises that an alternative to a provision is justified if it achieves good governance. At the same time, companies are prepared to be as accountable and transparent as possible. Departures from a code provision are not presumed to be breaches because accompanying explanations should provide insight into how companies think about improving their corporate governance. Reportedly, the three European banks did not specify the details on certain matters, including; the remuneration benchmarking exercise, data collection regarding high earners, assessment of the suitability of members of the management body and key function holders, and their internal governance matters.

In this light, the European Banking Authorities (EBA) will shortly collect data on remuneration benchmarking, as it shall gather relevant information on the number of natural persons earning EUR 1 million or more per financial year (EBA, 2014a, 2014b). This data collection aims at ensuring a high level of transparency regarding the remuneration practices within the EU. These guidelines will be used to benchmark trends and practices. In addition, there are other guiding principles that set out the process, criteria and minimum requirements for assessing the suitability of members of the management body and key function holders (EBA, 2015). These recommendations followed EBA's (2011) guidelines on internal governance of institutions and the banking systems, as a whole. This document was primarily aimed at enhancing and consolidating supervisory expectations, and to ultimately improve the sound implementation of internal governance arrangements. In this case, this research reported how the three banks have thoroughly explained their organisational structure with well defined, transparent disclosures about their board members' lines of responsibility. They also demonstrated that they had set effective processes to identify, manage, monitor and report the potential risks that they might be exposed to. Notwithstanding they all described their internal control mechanisms to a certain extent. Perhaps, there were minor reporting 
deficiencies in terms of oversight of the supervisory function, risk management and internal control frameworks coupled with the riskiness of the products and services they offer. Nevertheless, the three banks have provided details on their sound administrative and accounting procedures. They also shed light on how they determine and structure their remuneration policies.

Arguably, further reforms may help to strengthen the oversight and management of European banks. For instance, the potential conflicts of interest of directors and controlling shareholders in governing bodies as well as the cross-appointments within financial institutions could be deterred and prevented with clearly laid-out policies in this regard. Responsible corporate governance necessitates due diligence at all times, particularly on controlling shareholders. These case studies have shown that at the moment there are stringent regulations on lending parties among other issues. There was mention of certain requirements for board qualification and composition. Interestingly, the latest EU directive has also brought up the subject of diversity at the corporate board levels. It has recommended specific criteria that were aimed at fostering wider diversity in the composition of boards (e.g. age, gender, educational and professional background). The EU Commission has even suggested that this transparency requirement complements the draft directive about the presence of women on boards.

Debatably, most of the recent provisions could be perceived as 'over-prescriptive' by certain European entities; as large undertakings are expected to incorporate externalities to enhance activism toward responsible corporate governance (Acharya and Volpin, 2010). Of course, any restrictions on ownership and voting rights (one member-one vote) could possibly weaken market diligence and the bank's capacity to raise capital from outside sources. For this reason, many jurisdictions are increasingly protecting their minority shareholders. For example, in the Netherlands, the minority shareholders are entitled to present lists of Board candidates when they own a minimum amount of share capital. In the Italian context, the banks' by-laws will establish relevant mechanisms according to how the board seats are distributed among slates (Borsa Italiana, 2015). Generally, the slate receiving the highest number of votes takes all the board seats, but the quota reserves at least one seat for the minority shareholders. In this case, the representative of the minority shareholders chairs the internal control body in Italy. There are instances where corporations could decide to get around responsible corporate governance requirements relating to fiduciary duties, executive 
salaries, and the divulgation of the entities shareholders' identity and their voting rights, tax incentives, loyalty dividends, among other issues. Notwithstanding, there are other contentious matters including; preventing human rights abuses and/or fighting corruption and bribery (EU, 2014).

\section{Conclusions and Implications}

The past EU directives and recommendations on corporate governance disclosure requirements; shareholder rights and non-financial accounting for the listed companies were implemented across all European states. Moreover, many states, including Germany, Italy and the Netherlands have recently transposed the latest EU (2014) directive. The underlying rationale behind such a European directive was that corporate governance policies have an important role to play in achieving the broader economic objectives with respect to investor confidence, capital formation and allocation. Responsible corporate governance affects the cost for corporations to access finance for their growth prospects. Notwithstanding, the responsible principles could safeguard the stakeholders' rights (particularly shareholders' rights). Ideally, all stakeholders ought to be treated in fair, transparent and equitable terms. The EU's corporate governance principles are providing a comprehensive framework that reassures shareholders that their rights are protected. This is of significant importance in today's globalised capital markets. International flows of capital enable companies to access financing from a much larger pool of investors. If companies and countries are to reap the full benefits of the global capital market, and if they are to attract long-term "patient" capital, corporate governance arrangements must be trustworthy, well understood across borders and adhere to internationally accepted principles. Even if corporations do not rely on foreign sources of capital, a credible corporate governance framework, supported by effective supervision and enforcement mechanisms; will help foster confidence in domestic investors, reduce the cost of capital, strengthen the good functioning of financial markets, and ultimately induce more stable sources of financing.

There is no single model of good corporate governance. However, the guiding principles including the EU's Directive on Disclosure of Transparency 2013/50/EU and the EU's Directive on Non-Financial Disclosures 2014/95/EU (2014) underpin responsible corporate governance in Europe. However, responsible corporate governance principles are nonbinding and are not intended as prescriptions for national legislation. These principles seek to identify objectives as they suggest various means for achieving them. The European 
corporate governance principles aim to provide a robust, yet flexible reference for policy makers and market participants to develop their own frameworks for corporate governance. To remain competitive in a changing world, corporations must innovate and adapt their corporate governance practices. This way, they can meet new demands and grasp new opportunities. The European governments have an important responsibility for shaping an effective regulatory framework that provide sufficient guidelines and flexibility that allow markets to respond to new stakeholders' expectations. The EU directives are widely used as a benchmark by individual European states. The principles themselves are evolutionary in nature and are reviewed in the light of significant circumstantial changes that may arise in corporate governance. This contribution suggests that effective corporate governance frameworks are critical to the proper functioning of the banking sector and the respective macro economy as a whole. It reported how the three major European banks and their supervisors are operating to achieve robust and transparent risk management as they promote public confidence in their board committees. This way they uphold the safety and soundness of the European financial services industry.

\section{Limitations and Future Research Avenues}

There are many factors that could influence the companies' active engagement in corporate governance behaviours and their adequate disclosure in annual reports. The composition of the decision-making bodies and the way how they define their activities could be considered as challenging in terms of both accountability and transparency toward stakeholders.

Although, all member states are transposing new EU directives; to date, there are no specific, obligatory requirements in relation to the type of non-financial indicators and metrics that should be used as a yardstick for corporate governance disclosures. Moreover, there is a need for further empirical evidence that should analyse how the European principles may (or may not) affect other large undertakings, including state-owned organisations or nongovernmental organisations. For instance, IMF (2013) reported a challenging issue facing many financial services firms. It reported that foundations constitute one of the major shareholders in banks. Apparently, they hold 20 percent or more of bank capital in Italy. Therefore, these foundations can control boards with a small share of ownership, often through shareholders' agreements. On the other hand, in Anglo-Saxon countries, foundations are increasingly investing in a broadly diversified range of sectors and are not inextricably linked to the ownership of the banks' shares (IMF, 2014). Their board members typically 
include investment experts, professors, researchers, and professionals, thereby allowing for a wide range of specific knowledge. They often mandate an Investment Committee that is made up of investment professionals, that are supervised by the Boards; to draft investment policies as they set investment targets (IMF, 2014).

In conclusion, this exploratory research shed light on the corporate governance policies of three major international banks, operating in the European context. Hence, further research may use other methodologies and sampling frames. Future research avenues exist on corporate governance disclosures in different industry sectors. This research has analysed three corporate governance codes out of twenty-eight member countries within the European Union. A wider selection of countries could have probably given a better understanding of how different contexts could have transposed the EU's (2014) directive. This contribution has clearly indicated that there are external forces, including institutional factors that can influence and shape responsible corporate governance and their disclosures. Future research could also explain how internal pressures such as shareholder activism could restrain or alter the organisations' actions.

\section{References}

Abbott, L. J., Parker, S., Peters, G. F., and Rama, D. V. (2007). Corporate governance, audit quality, and the Sarbanes-Oxley Act: Evidence from internal audit outsourcing. The Accounting Review, 82(4), 803-835.

Acharya, V. V. and Volpin, P. F. (2009). Corporate governance externalities*. Review of Finance, rfp002.

Adams, C. (2002). Internal organisational factors influencing corporate social and ethical reporting: Beyond current theorizing. Accounting, Auditing and Accountability Journal, 15(2), 223-250. 
Arora, P., and Dharwadkar, R. (2011). Corporate governance and corporate social responsibility (CSR): The moderating roles of attainment discrepancy and organization slack. Corporate governance: an international review, 19(2), 136-152.

Banerjee, S.B. (2008). Corporate social responsibility: The good, the bad and the ugly. Critical sociology, 34(1), 51-79.

Borsa Italiana (2015). Corporate Governance Code (July 2015) http://www.borsaitaliana.it/borsaitaliana/regolamenti/corporategovernance/corporategovernan ce.en.htm accessed on the 10th February 2016.

Camilleri, M. A. (2015a). Valuing stakeholder engagement and sustainability reporting. Corporate Reputation Review, 18(3), 210-222.

Camilleri, M. A. (2015b). Environmental, social and governance disclosures in Europe. Sustainability Accounting, Management and Policy Journal, 6(2), 224-242.

CERES (2012). Executive compensation tied to ESG performance. The CERES roadmap for sustainability. http://www.ceres.org/roadmap-assessment/progress-report/performance-byexpectation/governance-for-sustainability/executive-compensation-tied-to-esg-performance-1 accessed on the 2nd February 2016.

Chan, M. C., Watson, J., and Woodliff, D. (2014). Corporate governance quality and CSR disclosures. Journal of Business Ethics, 125(1), 59-73.

DCGC (2016). Dutch Corporate Governance Code http://commissiecorporategovernance.nl/dutch-corporate-governance-code accessed on the 14th February 2016.

DCGK (2016). Deutscher Corporate Governance Kodex http://www.dcgk.de/en/home.html accessed on the 15th February 2016. 
Del Baldo, M. (2012). Corporate social responsibility and corporate governance in Italian SMEs: The experience of some "spirited businesses". Journal of Management \& Governance, 16(1), 1-36.

Deutsche Bank (2015). Deutsche Bank Annual Report 2014: Corporate Governance Statement I Corporate Governance Report https://annualreport.deutschebank.com/2014/ar/supplementary-information/corporate-governance-report.html

Donaldson, T. and Preston, L. E. (1995). The stakeholder theory of the corporation: Concepts, evidence, and implications. Academy of management Review, 20(1), 65-91.

EBA (2011) Guidelines on Internal Governance (GL44)

https://www.eba.europa.eu/regulation-and-policy/internal-governance/guidelines-on-internalgovernance

EBA (2014a) Guidelines on the remuneration benchmarking exercise https://www.eba.europa.eu/regulation-and-policy/remuneration/guidelines-on-theremuneration-benchmarking-exercise

EBA (2014b) Guidelines on the data collection exercise regarding high earners

https://www.eba.europa.eu/regulation-and-policy/remuneration/guidelines-on-the-datacollection-exercise-regarding-high-earners

EBA (2015) Guidelines on the assessment of the suitability of members of the management body and key function holders (EBA/GL/2012/06) https://www.eba.europa.eu/regulation-and-policy/internal-governance/guidelines-on-theassessment-of-the-suitability-of-members-of-the-management-body-and-key-functionholders

ECCJ (2014). Assessment of the EU Directive on the disclosure of non-financial information by certain large companies. available at: http://business- 
humanrights.org/sites/default/files/media/documents/eccj-assessment-eu-non-financialreporting-may-2104.pdf (accessed 3 January 2015).

Eisenhardt, K. M. (1989). Building theories from case study research. Academy of Management Review, 14(4), 532-550.

EU (2014). EU adopts reporting obligations for human rights and other "non-financial" information. Lexology http://www.lexology.com/library/detail.aspx?g=41edd30b-e08c4d26-ba6f-b87158b5ee85 accessed on the 10th February 2016.

Fairclough, N. (2003). Analysing discourse: Textual analysis for social research. Psychology Press.

Friedman, M. (1970). The social responsibility of business is to increase its profits. New York Times Magazine, September 13, 32-33.

Fuentes-García, F. J., Núñez-Tabales, J. M. and Veroz-Herradón, R. (2008). Applicability of corporate social responsibility to human resources management: Perspective from Spain. Journal of Business Ethics, 82(1), 27-44.

Harford, J., Mansi, S. A., \& Maxwell, W. F. (2012). Corporate governance and firm cash holdings in the US. In Corporate Governance (pp. 107-138). Springer Berlin Heidelberg.

Hambrick, D. C., Werder, A. V. and Zajac, E. J. (2008). New directions in corporate governance research. Organization Science, 19(3), 381-385.

IMF (2013). Italy: Financial System Stability Assessment https://www.imf.org/external/pubs/ft/scr/2013/cr13300.pdf accessed on the 22nd February 2016.

IMF (2014). Reforming the Corporate Governance of Italian Banks https://www.imf.org/external/pubs/ft/wp/2014/wp14181.pdf accessed on the 22nd February 2016. 
ING (2014). Corporate Governance http://www.ing.com/About-us/CorporateGovernance/Legal-structure-and-Regulators.htm accessed on the 14th February 2016.

Jo, H. and Harjoto, M. A. (2011). Corporate governance and firm value: The impact of corporate social responsibility. Journal of business ethics, 103(3), 351-383.

Jizi, M. I., Salama, A., Dixon, R. and Stratling, R. (2014). Corporate governance and corporate social responsibility disclosure: Evidence from the US banking sector. Journal of Business Ethics, 125(4), 601-615.

Jones, I., and Pollitt, M. (2004). Understanding how issues in corporate governance develop: Cadbury Report to Higgs Review. Corporate Governance: An International Review, 12(2), $162-171$.

Krippendorff, K. (2012). Content analysis: An introduction to its methodology. Sage.

Lau, C., Lu, Y. and Liang, Q. (2014). Corporate Social Responsibility in China: A Corporate Governance Approach. Journal of Business Ethics, 1-15.

Lau, K. L. A. and Young, A. (2013). Why China shall not completely transit from a relation based to a rule based governance regime: a Chinese perspective. Corporate Governance: An International Review, 21(6), 577-585.

Lazonick, W., and O'sullivan, M. (2000). Maximizing shareholder value: a new ideology for corporate governance. Economy and society, 29(1), 13-35.

Manasakis, C., Mitrokostas, E. and Petrakis, E. (2013). Certification of corporate social responsibility activities in oligopolistic markets. Canadian Journal of Economics/Revue canadienne d'économique, 46(1), 282-309.

Mason, C. and Simmons, J. (2014). Embedding corporate social responsibility in corporate governance: A stakeholder systems approach. Journal of Business Ethics, 119(1), 77-86. 
McKeone, Dermot H. (1995). Measuring Your Media Profile: A general introduction to media analysis and PR evaluation for the communications industry. Gower Press Ltd, Hampshire, England.

Miller, T. and del Carmen Triana, M. (2009). Demographic diversity in the boardroom: Mediators of the board diversity-firm performance relationship. Journal of Management studies, 46(5), 755-786.

Paine, L. S. (1994). Managing for organizational integrity. Harvard business review, 72(2), 106-117.

Rahim, M. M. and Alam, S. (2014). Convergence of corporate social responsibility and corporate governance in weak economies: The case of Bangladesh. Journal of Business Ethics, 121(4), 607-620.

Relbanks (2015) Top European Banks http://www.relbanks.com/top-european-banks/assets accessed on the 26th April, 2016.

Schneider, A. and Scherer, A. G. (2015). Corporate governance in a risk society. Journal of Business Ethics, 126(2), 309-323.

Sharif, M. and Rashid, K. (2014). Corporate governance and corporate social responsibility (CSR) reporting: an empirical evidence from commercial banks (CB) of Pakistan. Quality \& Quantity, 48(5), 2501-2521.

Shleifer, A., \& Vishny, R. W. (1997). A survey of corporate governance. The journal of finance, 52(2), 737-783.

Unicredit (2015). Governance Systems and Policies https://www.unicreditgroup.eu/en/governance/governance-system-and-policies.html accessed on the 16th February 2016.

Young, S. and Thyil, V. (2014). Corporate social responsibility and corporate governance: Role of context in international settings. Journal of Business Ethics, 122(1), 1-24. 